\title{
TINGKAT AKURASI EMPERICAL AREA REDUCTION METHOD (EARM) UNTUK MEMPREDIKSI KURVA H-V DI WADUK MRICA
}

\author{
Puji Utomoo $^{1)}$, Nanda Melyadi Putri ${ }^{2)}$, Ajeng Yandhika Fitriana ${ }^{3)}$ \\ ${ }^{1,2,3)}$ Program Studi Teknik Sipil, Universitas Teknologi Yogyakarta, Yogyakarta, 55164 \\ Email:puji.utomo@staff.uty.ac.id ${ }^{1)},{\text { nanda.putri@staff.uty.ac.id }{ }^{2} \text {, }}^{2}$ \\ yandhikafitriana@gmail.com ${ }^{3)}$
}

DOI: http://dx.doi.org/10.29103/tj.v11i1.387

(Received: September 2020 / Revised: December 2020 / Accepted: January 2021)

\begin{abstract}
Abstrak
Sedimentasi waduk merupakan permasalahan yang sangat penting dalam kegiatan operasi dan pemeliharaan waduk. Perkembangan sedimentasi waduk dapat dilihat dari hubungan antara kapasitas tampungan dan elevasi atau sering disebut kurva $\mathrm{H}-\mathrm{V}$. Kurva ini dapat dibuat dengan melakukan pengukuran echosounding secara periodik. Namun, dalam beberapa kasus banyak waduk tidak melakukan ini karena pertimbangan biaya, oleh karena itu, perlu digunakan pendekatan model seperti Emperical Area Reduction Method (EARM). Penelitian ini bertujuan untuk mengetahui tingkat akurasi model distribusi sedimen EARM agar dapat digunakan untuk memprediksi kurva H-V.Lokasi penelitian inidi Waduk Mrica yang berada di Kecamatan Bawang, Kabupaten Banjarnegara.Tahapan analisis meliputi menganalisis kondisi sedimentasi waduk, menganalisis prediksi kurva $\mathrm{H}-\mathrm{V}$ dengan model EARM, dan mengevaluasi kesesuaian model untuk mengetahui tingkat akurasi berdasarkan nilai korelasi (R) dan Relative Mean Error (RME).Waduk Mrica mengalami tingkat sedimentasi yang sangat tinggi dengan laju sedimentasi waduk rerata sebesar 3,951 juta $\mathrm{m}^{3} /$ tahun. Laju sedimentasi berangsur mengalami penurunan akibat mulai adanya pengelolaan sedimentasi di Waduk Mrica. Pendekatan dengan model Emperical Area Reduction Method (EARM) untuk memprediksi kurva H-V sangat ideal digunakan di Waduk Mrica. Hasil evaluasi dari prediksi model terlihat nilai korelasi mendekati kondisi ideal $\left(\mathrm{R}^{2}=1\right)$ dan nilai RME hanya bekisar antara $0-11 \%$, artinya prediksi kurva $\mathrm{H}-\mathrm{V}$ dengan model EARM menunjukkan korelasi yang sangat kuat dengan data lapangan dari pengukuran echosounding.
\end{abstract}

Kata kunci: Distribusi Sedimen, Empirical Area Reduction Method (EARM), Kurva $H$-V, Sedimentasi Waduk, Waduk Mrica

\begin{abstract}
Reservoir sedimentation is a very important issue in reservoir operation and maintenance activities. The development of reservoir sedimentation can be seen from the relationship between the reservoir capacity and elevation or often is called H-V curve. This curve can be made with periodic echosounding measurements. However, in some cases many reservoirs don't perform due to cost considerations, therefore, it requires a modeling approach such asEmperical Area Reduction Method (EARM). This study aims to determine the level of accuracy of EARM sediment distribution model so that it can be used to predict the H-V curve. The location of this research was in Mrica Reservoir, Bawang District, Banjarnegara Regency. The stages of analysisinclude: analyzing the sedimentation conditions ofreservoir, analyzing the $\mathrm{H}$ -
\end{abstract}

Tingkat Akurasi Emperical Area Reduction Method (EARM) Untuk Memprediksi Kurva H-V di Waduk Mrica - Puji Utomo, Nanda Melyadi Putri, Ajeng Yandhika Fitriana 
V curve prediction withEARM model, and evaluating the suitability of the model to determine the level of accuracy based on the correlation value (R) and Relative Mean Error (RME). As results, Mrica Reservoir experienced a very high sedimentation rate with an average reservoir sedimentation rate of 3,951 million $\mathrm{m}^{3} / \mathrm{year}$. The sedimentation rate has gradually decreased due tosedimentation management in the Mrica Reservoir. The Emperical Area Reduction Method (EARM) approach to predict the $\mathrm{H}-\mathrm{V}$ curve is ideal for used inMrica Reservoir. The evaluation results ofprediction model show that correlation value approach ideal conditions $\left(\mathrm{R}^{2}=1\right)$ and $\mathrm{RME}$ value is only in the range of $0-11 \%$, It meaning that $\mathrm{H}-\mathrm{V}$ curve prediction with the EARM model shows a very strong correlation with field data from echosounding measurements.

Keywords: Sediment Distribution, Empirical Area Reduction Method (EARM), H-V Curve, ReservoirSedimentation, Mrica Reservoir.

\section{Latar Belakang}

Waduk merupakan infrastuktur di bidang Sumber Daya Air (SDA) yang memiliki banyak manfaat, diantaranya: untuk keperluan irigasi pertanian, pengendalian banjir, perikanan, kebutuhan air minum, obyek wisata, dan sebagai tanggul penampung air limpasan dari sungai ke waduk. Sedimentasi waduk merupakan permasalahan yang sangat penting dalam kegiatan operasi dan pemeliharaan waduk. Sedimentasi waduk yang tidak terkendali akan sangat mempengaruhi unjuk kerja waduk, karena menyebabkan usia layanan waduk tidak sesuai dengan umur perencanaan. Banyak waduk di Indonesia khususnya di Pulau Jawa, yang mengalami sedimentasi akibat sedimen yang berasal dari erosi lahan. Kondisi ini disebabkan karena kerusakan hutan (deforestasi) serta alih guna lahan di daerah hulu DAS, intensitas curah hujan yang tinggi, sifat agregat tanah yang mudah lepas, dan banyak daerah di Pulau Jawa yang memiliki topografi berupa lereng yang curam. Waduk Mrica merupakan salah satu waduk di Pulau Jawa yang saat ini mengalami tingkat sedimentasi yang sangat tinggi. Produksi sedimen tahunan dari lahan mencapai 7,358 juta $\mathrm{m}^{3} /$ tahun(Legono, 2006). Laju endapan sedimen di Waduk Mrica mencapai 4,097 juta $\mathrm{m}^{3} / \operatorname{tahun(Utomo,~2017),~sementara~}$ menurutWidarto (2017) laju endapan sedimen di Waduk Mrica rata-rata mencapai 4,2 juta $\mathrm{m}^{3} /$ tahun. Penelitian sejenis Febrianidan Utomo (2018)menunjukkan volume sedimen yang mengendap sebesar 3,956 juta $\mathrm{m}^{3} /$ tahun. Dalam aspek keberlanjutan fungsi waduk, perlu dilakukan program monitoring dan evaluasi untuk mengetahui perkembangan sedimentasi waduk yang terjadi. Salah satu indikator yang digunakan melalui perubahan kurva karakteristik tampungan (kurva $\mathrm{H}-\mathrm{V}$ ) akibat adanya sedimen yang masuk ke waduk. Kurva ini selanjutnya digunakan untuk pengambilan kebijakan pengelola waduk untuk menentukan pola operasi waduk, sebagaimana fungsi waduk baik sebagai pengendali banjir maupun dari aspek pemanfaatan air untuk irigasi, air baku, maupun PLTA.

Sedimentasi yang tidak terkendali akan mengakibatkan perubahan kurva $\mathrm{H}$ $\mathrm{V}$ yang drastis, sehingga mengurangi efisiensi dan efektivitas waduk dalam mengendalikan banjir dan memenuhi kebutuhan air irigasi, air baku, maupun PLTA.

Kurva $\mathrm{H}-\mathrm{V}$ biasanya didapatkan dari hasil analisis data pengukuran pemeruman (echosounding) di waduk. Biasanya pengukuran echosounding akan menghasilkan data kontur waduk, kurva $\mathrm{H}-\mathrm{V}$, kapasitas tampungan, dan laju endapan sedimen per tahun.

Tingkat Akurasi Emperical Area Reduction Method (EARM) Untuk Memprediksi Kurva H-V di Waduk Mrica - Puji Utomo, Nanda Melyadi Putri, Ajeng Yandhika Fitriana 
Pengelola Waduk Mrica sudah cukup baik, karena rutin melakukan pengukuran echosounding secara periodik. Namun karena pertimbangan biaya pelaksanaan yang cukup mahal, waktu yang lama, dan masih dilakukan manual, sehingga diharapkan perlu adanya riset untuk memprediksi kurva $\mathrm{H}-\mathrm{V}$ tanpa melakukan pengukuran echosounding. Prediksi kurva H-V dapatdilakukan dengan pendekatan model distribusi sedimen yangtelah dikembangkan di luar negeri, salah satunya model Emperical Area Reduction Method (EARM). Model EARM dikembangkan oleh Borlandand Milller (1953)mengembangkan metode baru yang sering disebut dengan Area Reduction Method. Metode ini diusulkan berdasarkan data sedimentasi di 30 waduk di Amerika Serikat, yang selanjutnya diadopsi oleh U.S. Bureau of Reclamation,Morrisand Fan (1998). Metode ini selanjutnya dimodifikasi Lara (1965), bahwa total akumulasi dan distribusi sedimen pada berbagai ketinggian memiliki hubungan tertentu dengan bentuk waduk. Dalam perkembangannya, dilakukan berbagai evaluasi dan modifikasi persamaan model yang dikembangkan sebelumnya oleh para peneliti, seperti Strand and Pemberton (1982), Szechowyczand Qureshi (1973), melakukan penelitian dengan studi kasus waduk dengan kapasitas mendium dan besar. Borland (1970), Garde, et. al, (1978), Croley, et. al (1978), mengembangkan model persamaan pada tipe waduk delta.Model seperti Emperical Area Reduction Method (EARM) apabila diimplementasikan pada waduk di Pulau Jawa yang berbeda, harus dilakukan "beberapa penyesuaian dikarenakan berbedanya kondisi antara wilayah satu dengan yang lain serta perbedaan karakteristik waduk itu sendiri. (Michalec, 2015) menunjukkan bahwa kebanyakan metode empirik tidak mendapatkan hasil yang optimal ketika diaplikasikan untuk menentukan distribusi sedimen di wadukwaduk kecil. Peluang ini yang dilihat dalam melakukan penelitian ini, untuk mengetahui tingkat akurasi model distribusi sedimen yang sudah pernah dikembangkan, agar dapat digunakan untuk memprediksi kurva $\mathrm{H}-\mathrm{V}$ tanpa melakukan pengukuran echosounding.

\section{Metode Penelitian}

Lokasi penelitian ini di Waduk Mrica yang terletak di Kecamatan Bawang, Kabupaten Banjarnegara (Gambar 1). Waduk ini dibangun pada tahun 1984 dan selesai pada tahun 1898 dengan umur rencana waduk 50 tahun.

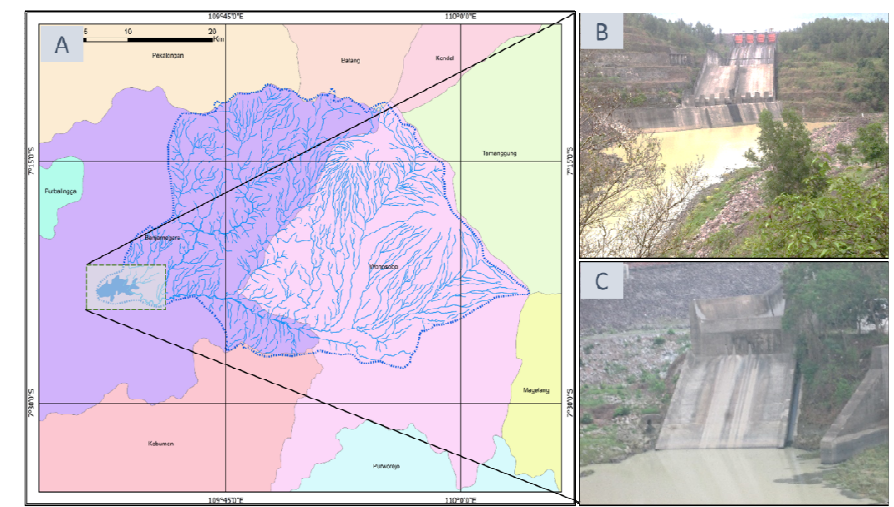

Gambar 1 Lokasi penelitian di Waduk Mrica (Utomo, 2018)

(a) Daerah Aliran Sungai (b) Bangunan Spillway (c) Drawdrown Culvert

Tingkat Akurasi Emperical Area Reduction Method (EARM) Untuk Memprediksi Kurva H-V di Waduk Mrica - Puji Utomo, Nanda Melyadi Putri, Ajeng Yandhika Fitriana 
Secara geografis Waduk Mrica terletak antara $109^{\circ} 6^{\prime} 00^{\prime \prime}-07^{\circ} 49^{\prime} 00^{\prime \prime}$ BT dan $7^{\circ} 17^{\prime} 04^{\prime \prime}-7^{\circ} 47^{\prime} 07^{\prime \prime}$ LS.

Daerah tangkapan air Waduk Mrica luasnya mencapai $957 \mathrm{~km}^{2}$ dan kapasitas tampungan sebesar 193,5 juta $\mathrm{m}^{3}$. Waduk Mrica memiliki 3 turbin untuk PLTA yang mampu menghasilkan listrik sebesar 580.000 MWH per tahun. Datadata yang diperlukan dalam penelitian ini adalah data sekunder yang diperoleh dari berbagai instansi, seperti: data pengukuran echosounding, data analisa butiran sedimen dasar waduk, data teknis waduk, dan data dokumen/laporan terdahulu. Setelah dilakukan studi kajian terdahulu dan pengumpulan data, maka selanjutnya dilakukan analisis data. Tahapan analisis data yang dilakukan dalam penelitian ini adalah sebagai berikut:

\subsubsection{Menganalisis kondisi sedimentasi waduk}

Analisis kondisi sedimentasi waduk berdasarkan data sekunder dari hasil pengukuran echosounding. Pengukuran dengan pemeruman akan menghasilkan gambaran profil melintang dan memanjang dasar waduk, selanjutnya dapat pula dihitung kapasitas tampungan waduk. Pemeruman dilakukan dengan menggunakan alat echosounder. Hasil analisis yang didapatkan berupa volume sedimen yang mengendap per tahun di waduk, prosentase kapasitas tampungan waduk, dan kurva $\mathrm{H}-\mathrm{V}$ pada kondisi eksisting.

\subsubsection{Menganalisis prediksi kurva $H-V$ dengan model EARM}

Dalam studi ini, digunakan metode distribusi sedimen dengan model Empirical Area Reduction Method yang dikembangkan oleh Borland-Miller (1953) untuk memprediksi kurva karakteristik tampungan (kurva H-V). Distribusi endapan sedimen dalam waduk dipengaruhi oleh bentuk waduk. Bentuk waduk dapat diklasifikasikan berdasarkan nilai $\mathrm{m}$, seperti diperlihatkan pada Tabel 1 . Nilai $\mathrm{m}$ adalah gradien garis hubungan antara kapasitas waduk dengan elevasi.

The Empirical Area Reduction Method menggunakan persamaan sebagai berikut:

$$
\mathrm{S}=\int_{0}^{\mathrm{y}^{0}} \mathrm{Ady}+\int_{0}^{\mathrm{H}} \mathrm{K} \text { a dy }
$$

di mana $\mathrm{S}$ adalah volume sedimen total yang diendapkan di dalam waduk $\left(\mathrm{m}^{3}\right), \mathrm{A}$ adalah luas waduk pada kedalaman y $\left(\mathrm{m}^{2}\right)$, dan $\mathrm{K}$ adalah konstanta untuk mengkonversikan luas sedimen relatif (a) ke dalam luas sedimen sebenarnya, 0 adalah elevasi dasar (asli) waduk, $\mathrm{y}_{0}$ adalah elevasi dasar waduk setelah $\mathrm{T}$ tahun, $\mathrm{H}$ adalah kedalaman total waduk ( $\mathrm{m})$, dan a adalah luas sedimen relatif.

Tabel 1 Klasifikasi waduk berdasarkan nilai m

\begin{tabular}{ccc}
\hline $\begin{array}{c}\text { Tipe } \\
\text { Waduk }\end{array}$ & Klasifikasi & Nilai m \\
\hline 1 & Lake & $3,5-4,5$ \\
\hline 2 & Flood plain foot hill & $2,5-3,5$ \\
\hline 3 & Hill & $1,5-2,5$ \\
\hline 4 & Normally empty & $1,0-1,5$ \\
\hline
\end{tabular}

Sumber: Borland dan Miller, 1953 dalam USBR, 1973 
Untuk menentukan distribusi luas tampungan waduk dan volume sedimen, Lara (1965) dalam USBR (1973) mengusulkan beberapa hubungan perbandingan antara luas sedimen relatif (a) dengan menggunakan kedalaman relatif waduk diukur dari dasar (p) bagi masing-masing tipe waduk seperti pada Tabel 2. sebagai berikut.

Tabel 2 Persamaan hubungan nilai a dan $\mathrm{p}$

\begin{tabular}{cc}
\hline Tipe Waduk & Persamaan \\
\hline 1 & $5,074 \mathrm{p}^{1,85}(1-\mathrm{p})^{0,35}$ \\
\hline 2 & $2,487 \mathrm{p}^{0,57}(1-\mathrm{p})^{0,41}$ \\
\hline 3 & $16,967 \mathrm{p}^{1,15}(1-\mathrm{p})^{2,32}$ \\
\hline 4 & $1,486 \mathrm{p}^{0,25}(1-\mathrm{p})^{1,34}$ \\
\hline Sumber: Lara, 1965 dalam USBR, 1973
\end{tabular}

Elevasi dasar waduk setelah $\mathrm{T}$ tahun (setelah terjadi pengendapan selama $\mathrm{T}$ tahun) dapat ditentukan dengan menggunakan tabel dan grafik hubungan antara kedalaman relatif (p) dan nilai $\mathrm{F}(\mathrm{h})$ seperti pada Gambar 2.

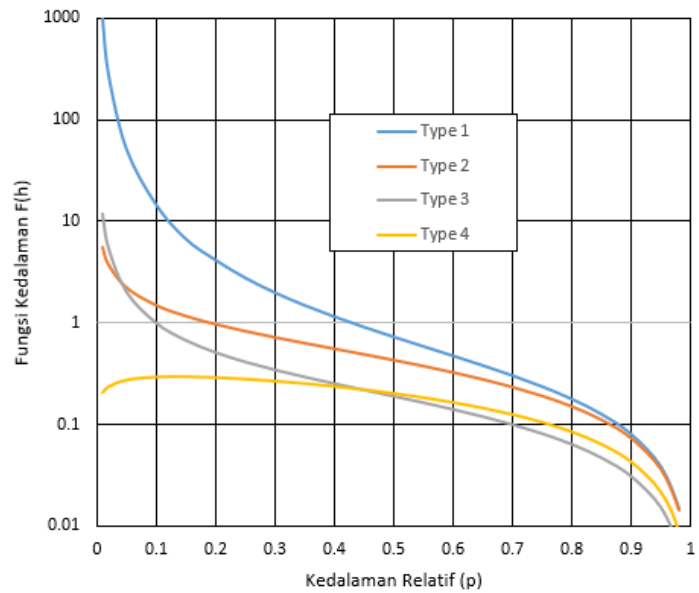

Gambar 2 Grafik hubungan kedalaman relatif (p) dan nilai $\mathrm{F}(\mathrm{h})$ sumber: dimodifikasi dariLara, 1965

Elevasi dasar waduk setelah $\mathrm{T}$ tahun (setelah terjadi pengendapan selama $\mathrm{T}$ tahun) dapat ditentukan dengan menggunakan tabel dan grafik hubungan antara kedalaman relatif (p) dan nilai $\mathrm{F}(\mathrm{h})$ seperti pada Gambar 2.

\subsubsection{Mengevaluasi tingkat akurasi model empirik yang dipilih}

Dari hasil perhitungan kurva $\mathrm{H}-\mathrm{V}$ terukur dengan kurva $\mathrm{H}-\mathrm{V}$ dari persamaan empirik, selanjutnya dilakukan evaluasi kesesuaian model untuk mengetahui tingkat akurasi model dengan menggunakan kriteria statistik, seperti: korelasi (R) dan Relative Mean Error (RME), sebagaimana disajikan pada persamaan berikut.

$$
R^{2}=\frac{\left(\sum_{i=1}^{n}\left(V_{m_{i}}-\bar{V}_{m_{i}}\right)\left(V_{o_{i}}-\bar{V}_{o_{i}}\right)\right)^{2}}{\sum_{i=1}^{n}\left(V_{m_{i}}-\bar{V}_{m_{i}}\right)^{2} \sum_{i=1}^{n}\left(V_{o_{i}}-\bar{V}_{o_{i}}\right)^{2}}
$$




$$
R M E=\frac{1}{n} \sum_{i=1}^{n} \frac{\left(V_{o_{i}}-V_{m_{i}}\right)}{V_{o_{i}}}
$$

di mana $V_{o}$ adalah nilai volume terukur dari data lapangan dan $V_{m}$ adalah nilai volume dari prediksi model EARM. Tingkat akurasi dari model dapat diketahui berdasarkan dari nilai korelasi $\left(\mathrm{R}^{2}\right)$ dan tingkat kesalahan (RME) dengan digolongkan berdasarkan Tabel 3.

Tabel 3Kriteria tingkat akurasi dari model

\begin{tabular}{cccc}
\hline No. & Korelasi $\left(\mathbf{R}^{2}\right)$ & RME $(\%)$ & Keterangan \\
\hline 1 & $0,00-0,19$ & $80-100$ & Sangat Lemah \\
\hline 2 & $0,2-0,39$ & $60-79$ & Lemah \\
\hline 3 & $0,4-0,59$ & $40-59$ & Sedang \\
\hline 4 & $0,6-0,79$ & $20-39$ & Kuat \\
\hline 5 & $0,8-1,0$ & $0-19$ & Sangat Kuat \\
\hline \multicolumn{4}{c}{ Sumber:Sugiyono, 2017 }
\end{tabular}

\section{Hasil dan Pembahasan}

Perkembangan kondisi sedimentasi di Waduk Mrica diolah dari data pemeruman (echosounding) yang dilakukan oleh PT. Indonesia Power. Lokasi pengukurun echosounding adalah di daerah genangan/waduk Mrica yang dibagi menjadi beberapa penampang, yaitu: 33 penampang pada sungai utama Serayu, 6 penampang pada anak sungai Kandangwangi, dan 5 penampang pada anak sungai Lumajang. Penempatan penampang-penampang ini dibuat sedemikian rupa sehingga efektif ditinjau dari segi biaya maupun waktu untu pelaksanaan, di samping dapat dianggap mewakili untuk perhitungan volumenya.

Perkembangan sedimentasi waduk dapat dilihat dari hubungan antara kapasitas tampungan dan elevasi atau sering disebut kurva H-V. Dalam penelitian ini, diambil data pengukuran echosounding pada awal tahun, tahun 2004, tahun 2014, dan tahun 2016. Hasil pengukuran echosounding tahun 2004 menyebutkan bahwa elevasi dasar waduk berada pada elevasi $+190,72 \mathrm{MSL}$ atau naik 30,72 m dari elevasi tahun 1988. Kenaikan elevasi dasar waduk bisa mencapai 1,92 $\mathrm{m} /$ tahun. Sementara hasil pengukuran echosounding tahun 2014 menyebutkan bahwa elevasi dasar waduk berada pada elevasi +200 MSL atau naik $40 \mathrm{~m}$ dari elevasi tahun 1988 dan naik 9,28 m dari elevasi tahun 2004. Sementara interval tahun 2014 ke 2016 cenderung tetap elevasi dasar waduknya. Kenaikan elevasi dasar waduk dari tahun $1988 \mathrm{~s} / \mathrm{d} 2014$ mencapai 1,5385 m/tahun, tetapi jika ditinjau dari tahun $2004 \mathrm{~s} / \mathrm{d} 2016$ kenaikan elevasi dasarmencapai 0,928 m.

Berdasarkan kondisi tersebut, dapat kita ketahui bahwa dari tahun $1988 \mathrm{~s} / \mathrm{d}$ tahun 2004 belum dilakukan pengelolaan sedimentasi secara siginifikan, sehingga menyebabkan laju endapan sedimen besar. Kondisi ini sedikit mulai berubah setelah dilakukan pengelolaan sedimentasi cukup baik antara kurun waktu tahun 2004 s/d tahun 2016, seperti: kegiatan penghijauan, penggelontoran sedimen (flushing), dan pembangunan check dam di alur sungai yang masuk ke waduk. Adapun kurva $\mathrm{H}-\mathrm{V}$ hasil analisis data pengukuran echosounding tahun 1988, 2004, 2014, dan 2016 dapat dilihat pada Gambar 3. 


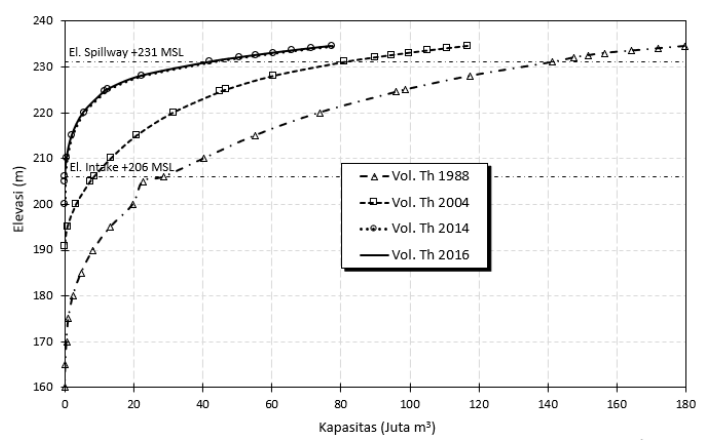

Gambar 3PerkembanganKurva H-V di Waduk Mrica 1988 - 2016

Dari hasil analisis data pengukuran echosounding, juga didapatkan besarnya laju sedimentasi waduk rerata per tahun. Hasil analisis menunjukkan bahwa laju sedimentasi waduk rerata pada periode $1988-2004$ sebesar 4,194 juta $\mathrm{m}^{3} /$ tahun. Laju sedimentasi rerata pada periode $2004-2014$ sebesar 3,916 juta $\mathrm{m}^{3} /$ tahun dan mengalami penurunan pada periode 2014 - 2016 yang laju sedimentasi rerata tahunan sebesar 3,744 juta $\mathrm{m}^{3} /$ tahun. Laju sedimentasi mengalami penurunan akibat adanya pengelolaan sedimentasi di Waduk Mrica. Adapun hasil analisis laju sedimentasi waduk disajikan pada Tabel 3.

Tabel 3 Laju sedimentasi rerata per tahun

\begin{tabular}{|c|c|c|c|}
\hline Tahun & $\begin{array}{l}\text { Kapasitas Total } \\
\quad\left(\mathrm{Juta}^{3}\right)\end{array}$ & $\begin{array}{l}\text { Total Endapan } \\
\quad\left(\text { Juta m}^{3}\right)\end{array}$ & $\begin{array}{l}\text { Laju Sedimentasi } \\
\text { (Juta } \mathrm{m}^{3} / \text { tahun) }\end{array}$ \\
\hline 1988 & 148,290 & - & - \\
\hline $1988-2004$ & 81,190 & 67,100 & 4,194 \\
\hline $2004-2014$ & 42,030 & 39,160 & 3,916 \\
\hline $2014-2016$ & 34,542 & 7,488 & 3,744 \\
\hline \multicolumn{3}{|c|}{ Laju sedimentasi rerata $\left(\right.$ Juta $\mathrm{m}^{3} /$ tahun $)$} & 3,951 \\
\hline
\end{tabular}

Kapasitas tampungan total Waduk Mrica sampai dengan tahun 2016 tersisa $23,29 \%$ dari kapasitas awal sebesar 148,290 juta $\mathrm{m}^{3}$. Penurunan kapasitas tampungan Waduk Mrica diakibatkan oleh sedimen yang mengendap sudah mencapai 76,71 \% dari kapasitas tampungan total awal. Kondisi ini menunjukkan bahwa perubahan kapasitas tampungan akibat sedimentasi relatif besar, sehingga menyebabkan umur layanan Waduk Mrica tidak sesuai lagi dengan umur perencanaan selama 60 tahun. Pengelola Waduk Mrica sebenarnya sudah cukup baik, karena rutin melakukan pengukuran echosounding secara periodik. Dalam beberapa kasus banyak waduk lain tidak melakukan ini karena pertimbangan biaya pelaksanaan yang cukup mahal, waktu yang lama, dan masih dilakukan manual, oleh karena itu, perlu pendekatan model untuk memprediksi kurva $\mathrm{H}-\mathrm{V}$ tanpa melakukan pengukuran echosounding, salah satunya dengan model Emperical Area Reduction Method (EARM). Model ini akan dievaluasi dengan kriteria statistik untuk mengetahui tingkat akurasi model dengan cara membandingkan antara data hasil pengukuran echosounding dengan hasil prediksi dari model di tahun yang sama. Hasil evaluasi dengan kriteria statistik antaramodel dengan data echosounding tahun 2004, 2014, dan 2016 disajikan pada Tabel 4. 
Tabel 4 Evaluasi dari model EARM dengan kriteria statistik

\begin{tabular}{ccccc}
\hline No. & Tahun & Korelasi $\left(\mathrm{R}^{2}\right)$ & RME $(\%)$ & Keterangan \\
\hline 1. & 2004 & 0,997 & 3,763 & Sangat Kuat \\
\hline 2. & 2014 & 0,998 & 11,054 & Sangat Kuat \\
\hline 3. & 2016 & 0,999 & 0,584 & Sangat Kuat \\
\hline
\end{tabular}

Nilai korelasi $\left(\mathrm{R}^{2}\right)$ yang berada pada rentang 0 sampai 1 menunjukkan bahwa model dapat diterima, tetapi perlu dilihat seberapa kuat hubungannya. Sementara hasil evaluasi menggunakan RME bahwa semakin kecil nilai RME, maka model tersebut akan semakin baik. Dari hasil evaluasi menunjukkan bahwa nilai korelasi mendekati kondisi ideal $\left(\mathrm{R}^{2}=1\right)$ dan nilai RME bekisar antara 0 11\%. Prediksi model tahun 2016 menunjukkan hasil yang paling ideal, sementara tingkat kesalahan RME terbesar terjadi pada prediksi model pada tahun 2014. Namun secara keseluruhan hasil analisis menunjukkan bahwa prediksi kurva $\mathrm{H}-\mathrm{V}$ dengan model EARM sangat ideal digunakan di Waduk Mrica. Evaluasi juga dapat dilakukan menggunakan grafik perbandingan data lapangan dengan hasil prediksi dengan model EARM, seperti disajikan pada Gambar 5.

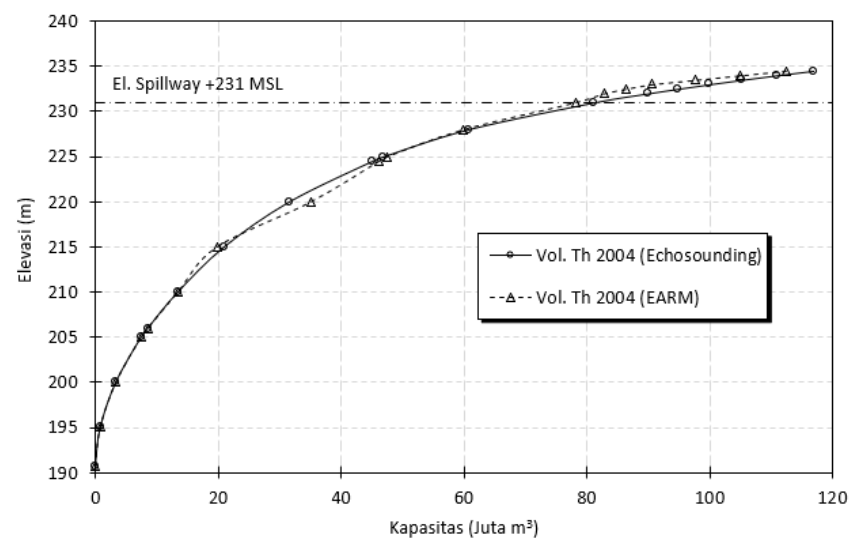

(a) Tahun 2004

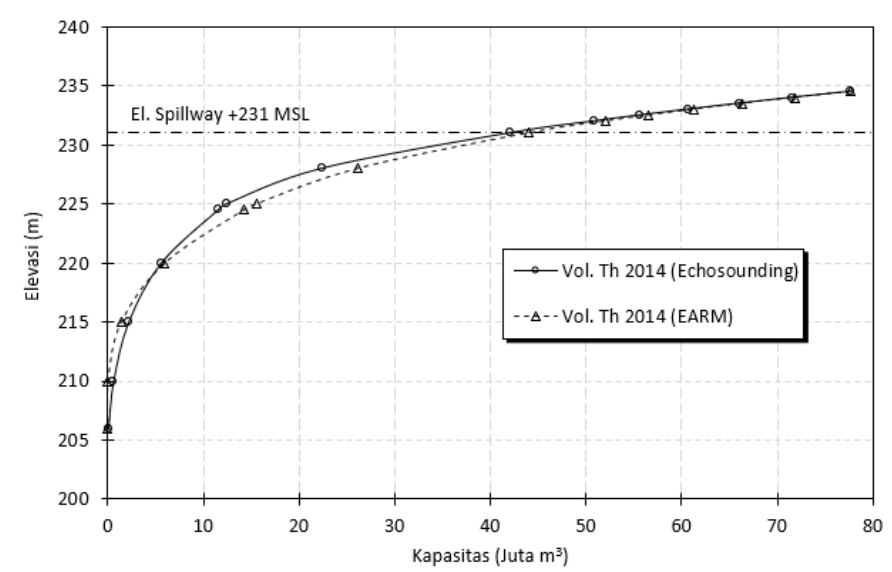

(b) Tahun 2014 


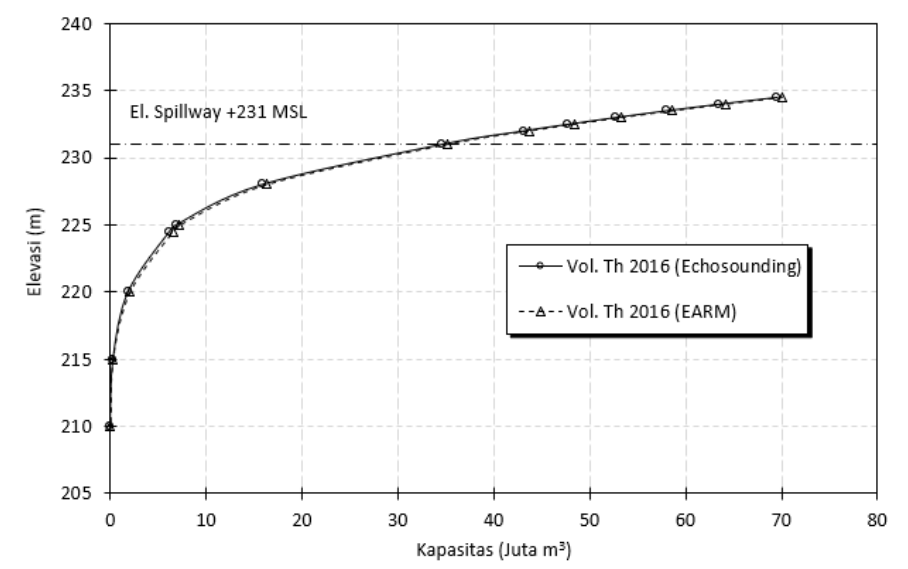

(c) Tahun 2016

Gambar 5 Grafik perbandingan prediksi model EARM dengan data lapangan

\section{Kesimpulan dan Saran}

\subsection{Kesimpulan}

Waduk Mrica mengalami tingkat sedimentasi yang sangat tinggi dengan laju sedimentasi waduk rerata sebesar $3,951 \mathrm{juta}^{3} /$ tahun. Laju sedimentasi terbesar terjadi pada periode 1988 - 2004 sebesar 4,194 juta $\mathrm{m}^{3} /$ tahun. Selanjutnya laju sedimentasi berangsur mengalami penurunan signifikan akibat mulai adanya pengelolaan sedimentasi di Waduk Mrica. Perkembangan sedimentasi waduk dapat dilihat dari hubungan antara kapasitas tampungan dan elevasi atau sering disebut kurva $\mathrm{H}-\mathrm{V}$ dengan melakukan pengukuran echosounding secara periodik. Namun, dalam beberapa kasus banyak waduk tidak melakukan ini karena pertimbangan biaya. Dalam penelitian ini didapatkan bahwa pendekatan dengan model Emperical Area Reduction Method (EARM) untuk memprediksi kurva H$\mathrm{V}$ sangat ideal digunakan dengan data di Waduk Mrica. Hasil evaluasi dari prediksi model terlihat nilai korelasi mendekati kondisi ideal $\left(\mathrm{R}^{2}=1\right)$ dan nilai RME hanya bekisar antara $0-11 \%$, artinya prediksi kurva $\mathrm{H}-\mathrm{V}$ dengan model EARM menunjukkan korelasi yang sangat kuat dengan data lapangan dari pengukuran echosounding.

\subsection{Saran}

Berdasarkan penelitian yang telah dilakukan, disarankan untuk melakukan penelitian lanjutan dengan menambah data pengukuran echosounding Waduk Mrica untuk mengevaluasi tingkat akurasi dari model EARM. Selain itu, disarankan untuk menggunakan pendekatan model lain selain EARM serta studi kasus dengan beberapa waduk lain khususnya yang ada di Pulau Jawa.

\section{Ucapan Terima Kasih}

Peneliti mengucapkan terima kasih kepada Laboratorium Hidrolika Program Studi Teknik SipilUniversitas Teknologi Yogyakarta sehingga penelitian dapat diselesaikan dengan baik. Selain itu, penelitan ini mendapat dukungan dari Hibah Penelitian Dosen Pemula tahun 2019. 


\section{Daftar Kepustakaan}

Borland, W. M., and Milller, C. R. (1953) 'Distribution of Sediment in Large Reservoirs', J. Hydraul. Eng. Div. ASCE, 84, pp. 1-18.

Borland, W. M. (1970) 'Reservoir Sedimentation', River Mechanics. Water Resource, 29, pp. 1-38.

Croley, T. E., Raja Roa, K. N., Karim, F. (1978) Reservoir Sedimentation Model with Continuing Distribution, Compaction and Slump. Iowa Institute of Hydraulic Research (IIHR) Report No. 198, The University of Iowa: Iowa City, IA, USA.

Febriani, P. dan Utomo, P. (2018) Kajian Tingkat Akurasi Model Efisiensi Tampungan (Trap Efficiency) Sedimen Di Waduk Mrica Jawa Tengah. Tugas Akhir. Program Studi Teknik Sipil. Universitas Teknologi Yogyakarta. Yogyakarta.

Garde, R. J., Swamee, P. K., Dalvi, M. E. (1978) 'Estimation of Progressive Deposition in Reservoirs', in Proceeding of the 47th Research Session of the CBIP , Hubli-Dharwar, Karnataka, pp. 1-50.

Lara, J. M. (1965) Revision of Procedure to Compute Sediment Distribution in Large Reservoirs . U. S. Bureau Reclamation: Denver, Colorado, USA.

Legono, D. (2006) 'Sedimentasi Waduk (Sedimentation Reservoir)', in Diktat kuliah. Yogyakarta: Jurusan Teknik Sipil dan Lingkungan, Fakultas Teknik, Universitas Gadjah Mada.

Michalec, B. (2015) 'Evaluation of An Empirical Reservoir Shape Function to Define Sediment Distributions in Small Reservoirs', Water (Switzerland), 7(8), pp. 4409-4426. doi: 10.3390/w7084409.

Morris, G. L., and Fan, J. 1998 (1998) Reservoir Sedimentation Handbook, New York: McGraw Hill.

Strand, R. I. and Pemberton, E. L. (1982) Reservoir Sedimentation Technical Guidelines for Bureau of Reclamation, US Bureau of Reclamation.

Sugiyono (2017) Statistik untuk Penelitian. Bandung: Alfabeta.

Szechowycz, R. W. and Qureshi, M. M. (1973) Reservoir Sedimentation Technical Guidelines for Bureau of Reclamation . U. S. Bureau Reclamation: Denver, Colorado, USA.

Utomo, P. (2017) 'Mrica Reservoir Sedimentation: Current Situation and Future Necessary Management', Journal of the Civil Engineering Forum, 3(2), p. 365. doi: 10.22146/jcef.26640.

Utomo, P. (2018) 'Prediksi Kurva Karakteristik Tampungan Waduk (Kurva H-V) Akibat Pengelolaan Sedimentasi di Waduk Mrica', in Prosiding Seminar Nasional IV Teknik Sipil, Malang, 13 September 2018.

Widarto, O. L. (2017) Kajian Erosi Lahan Di Daerah Tangkapan Waduk Panglima Besar Soedirman Dan Analisis Sedimentasi. Tugas Akhir. Yogyakarta: Universitas Gadjah Mada. 